\title{
A FORMAÇÃO SOCIOESPACIAL DE IGARAPÉ-MIRI E SEU ATUAL SIGNIFICADO NA REDE URBANA DO BAIXO TOCANTINS
}

\section{IGARAPÉ-MIRI'S SOCIO-SPATIAL FORMATION AND ITS CURRENT MEANING IN THE URBAN NETWORK OF LOW TOCANTINS}

\section{LA FORMACIÓN SOCIO-ESPACIAL DE IGARAPÉ-MIRI Y SU SIGNIFICADO ACTUAL EN LA RED URBANA DE BAJAS TOCANTINAS}

\begin{abstract}
Ederson Ferreira Lobo ${ }^{1}$ Gracileno Trindade Pimentel ${ }^{2}$

\section{Resumo}

Este trabalho tem como proposta compreender como se deu a formação socioespacial do município de Igarapé-Miri-Pa através de uma periodização, com ênfase na ocupação do espaço e o desenvolvimento de atividades econômicas no território, bem como mostrar o atual significado econômico do município na divisão territorial do trabalho do Baixo Tocantins. Para isso, o caminho metodológico adotado foi o de caráter qualitativo e quantitativo, através de entrevistas com moradores da região e o levantamento bibliográfico, tendo como suporte teórico de interpretação da realidade autores que utilizam o método dialético marxista. Com a pesquisa chegou-se aos seguintes resultados: as transformações socioespaciais ocorridas em Igarapé-Miri, a partir do século XVIII até os dias atuais, estiveram relacionadas, em grande parte, ao desenvolvimento de três principais atividades: exploração da madeira; cultivo da cana de açúcar; e o extrativismo do açaí. Igarapé-Miri está inserido na região do Baixo Tocantins como grande produtor e exportador de açaí, fato que vem provocando significativas transformações socioespaciais e conferindo a esse município um novo significado na rede urbana do Baixo Tocantins. Os resultados obtidos contribuíram para o entendimento de que o espaço é resultado direto das ações humanas com os elementos que o constituem e cada configuração ao longo do tempo é reflexo, sempre provisório, do modo de produção vigente, se constituindo também em condição para a reprodução desse modo de produção e novas relações sociais.
\end{abstract}

Palavras-chave: formação socioespacial, cadeia produtiva do açaí.

\section{Abstract}

This work aims to understand how the socio-spatial formation of the municipality of Igarapé-Miri-Pa took place through periodization, with an emphasis on the occupation of space and the development of economic activities in the territory, as well as showing the current economic significance of the municipality in territorial division of labor in the Lower Tocantins. For this, the methodological path adopted was that of a qualitative and quantitative character, through interviews with residents of the region and a bibliographic survey, having as theoretical support for interpreting reality authors who use the Marxist dialectic method. With the research, the following results were obtained: the socio-spatial changes that occurred in IgarapéMiri, from the 18th century to the present day, were related, in large part, to the development of three main activities: logging; cultivation of sugar cane; and the extraction of açaí. Igarapé-Miri is inserted in the region of the lower Tocantins as a major producer and exporter of açai, a fact that has been causing significant socio-spatial transformations and giving this municipality a new meaning in the urban network of the lower Tocantins. The results obtained contributed to the understanding that space is a direct result of human actions with the elements that constitute it and each configuration over time is a reflection, always provisional, of the current mode of production, also constituting a condition for reproduction. this mode of production and new social relations.

Keywords: socio-spatial formation, açaí production chain.

\footnotetext{
${ }^{1}$ E-mail: edersonlobo@yahoo.com.br

${ }^{2}$ E-mail: lenopimentel10@gmail.com
} 


\section{Resumen}

Este trabajo tiene como objetivo comprender cómo se llevó a cabo la formación socioespacial del municipio de Igarapé-Miri-Pa a través de la periodización, con énfasis en la ocupación del espacio y el desarrollo de actividades económicas en el territorio, así como mostrar la importancia económica actual del municipio en división territorial del trabajo en los Tocantins inferiores. Para ello, el camino metodológico adoptado fue el de carácter cualitativo y cuantitativo, a través de entrevistas con residentes de la región y una encuesta bibliográfica, teniendo como soporte teórico la interpretación de autores de la realidad que utilizan el método dialéctico marxista. Con la investigación, se obtuvieron los siguientes resultados: los cambios socioespaciales que ocurrieron en Igarapé-Miri, desde el siglo XVIII hasta la actualidad, se relacionaron, en gran parte, con el desarrollo de tres actividades principales: tala; cultivo de caña de azúcar; y la extracción de açaí. Igarapé-Miri se inserta en la región de los Tocantins inferiores como un importante productor y exportador de açaí, un hecho que ha causado transformaciones socioespaciales significativas y ha dado a este municipio un nuevo significado en la red urbana de los Tocantins inferiores. Los resultados obtenidos contribuyeron a la comprensión de que el espacio es un resultado directo de las acciones humanas con los elementos que lo constituyen y cada configuración en el tiempo es un reflejo, siempre provisional, del modo de producción actual, que también constituye una condición para la reproducción. Este modo de producción y nuevas relaciones sociales.

Palabras clave: formación socioespacial, cadena de producción de açaí.

\section{INTRODUÇÃO}

O espaço geográfico brasileiro e suas regiões foram formados ao longo do tempo como resultado de ações determinadas basicamente por interesses externos. Desde o século XVI até os dias atuais o que se observa é a expansão de atividades econômicas sobre o espaço voltadas a atender interesses de agentes vinculados à expansão do modo de produção capitalista (HARVEY, 2005). Foi assim desde o período colonial, com o desenvolvimento de ciclos econômicos, até os dias atuais, no período denominado por Santos (2008) de meio técnico científico informacional.

A produção deste artigo foi motivada por duas questões centrais: quais os principais fatores que contribuíram para a formação socioespacial do município de Igarapé-Miri ao longo do tempo? Qual o papel ou novo significado do município na divisão territorial do trabalho do Baixo Tocantins? Diante dessas questões, a pesquisa buscou proporcionar a compreensão a respeito da formação socioespacial do Município de Igarapé-Miri-Pa através de uma periodização, desde o início do século XVIII aos dias atuais, com ênfase na ocupação do espaço e o desenvolvimento de atividades econômicas que contribuíram para a reestruturação espacial e o estabelecimento da base ou significado desse município na divisão territorial do trabalho do Baixo Tocantins ${ }^{3}$ ao longo do tempo, bem como o entendimento a respeito do seu atual significado econômico desempenhado no contexto de expansão de atividades agrícolas e extrativistas na Amazônia como grande produtor e exportador de açaí.

\footnotetext{
3 O Baixo Tocantins segundo Edir Pereira (2014) é uma configuração territorial da Amazônia brasileira, que compreende atualmente os territórios constituídos em torno do eixo de circulação do rio Tocantins, abaixo da Usina Hidrelétrica instalada em Tucuruí, no nordeste do Estado do Pará, abrangendo municípios como Baião, Cametá, Mocajuba, Igarapé-Miri, Limoeiro do Ajuru, Abaetetuba e Barcarena.
} 
O trabalho e seus resultados são de suma importância, tanto na esfera do pensamento geográfico como histórico, pois ajuda a compreender que a formação socioespacial de Igarapé-Miri esteve relacionada, em grande parte, a fatores ligados ao desenvolvimento de algumas atividades econômicas no território, como a atividade madeireira, o cultivo da cana de açúcar e o extrativismo do açaí. Além disso, a periodização com a identificação da base econômica em diferentes momentos, permitiu evidenciar a atual base ou significado que o município assumiu na divisão territorial do trabalho da região do Baixo Tocantins, se inserindo no contexto local, regional, nacional e global como grande produtor e exportador de açaí.

Além do resumo, introdução e considerações finais, para a demonstração dos resultados, procurouse dividir o artigo em duas partes de forma a contemplar os propósitos ou objetivos mencionados. Em um primeiro momento do trabalho discorre-se sobre o conceito de formação socioespacial utilizando como base teórica o entendimento de Milton Santos sobre o assunto. Assim, procura-se mostrar que a intenção da ação social sobre o espaço se constitui em elemento fundamental para a garantia de reprodução de novas configurações espaciais que, por sua vez, garantem novas relações sociais e seus desdobramentos de intenções, como a manutenção e reprodução do capital.

Em seguida, faz-se uma historiografia, baseada em pesquisa bibliográfica, documental e entrevistas a respeito da ocupação e formação socioespacial de Igarapé-Miri, considerando o desenvolvimento de algumas atividades econômicas que se deram no território desde as primeiras aglomerações humanas no século XVII até os dias atuais, como o extrativismo madeireiro, o cultivo da cana de açúcar, e, mais recentemente, o extrativismo do açaí, que confere ao município um novo significado econômico na divisão territorial do trabalho na região do Baixo Tocantins como maior produtor e exportador desse recurso natural, garantindo-lhe visibilidade e iteração econômica, expressando centralidade em variadas escalas espaciais.

Ao final, são feitas algumas considerações a respeito dos resultados obtidos em relação à sucessão das atividades econômicas ao longo do tempo que implicaram no processo de transformação e estruturação que o espaço e sociedade sofreram durante os períodos mencionados, bem como a respeito do novo significado de Igarapé-Miri na rede urbana do Baixo Tocantins no intuito de comprovar a relevância da pesquisa.

\section{A FORMAÇÃO SOCIOESPACIAL COMO TEORIA E MÉTODO}

A Formação Socioespacial, consiste numa categoria utilizada em obras clássicas do materialismo histórico dialético, criada e empregada para o desenvolvimento do pensamento científico, sobretudo, no pensar sobre a sociedade e a economia. Milton Santos, por meio dessa teoria e método, desenvolveu o estudo dialético a respeito da sociedade e o espaço. O modo de produção seja primitivo, comunitário, feudal, capitalista, enfim, acontece num dado espaço, num dado período de tempo, entretanto, a condição de homogeneidade socioespacial é descartada. A estrutura político-ideológica da sociedade estabelece a produção social do espaço, legitimando através das formas espaciais, as ações, o nível de complexidade das funções e das relações praticadas no grupo. 
Na perspectiva capitalista, "todos os processos que juntos formam o modo de produção (produção, circulação, distribuição, consumo), são históricos e espacialmente determinados num movimento conjunto, e isto através de uma formação social" (SANTOS, 1979, p. 14). Ainda, segundo os pressupostos do método marxista, "o espaço é fundamentalmente social e histórico, evolui no quadro diferenciado das sociedades e em relação com as forças externas, de onde mais frequentemente lhes provém os impulsos" (SANTOS, 1979, p. 10).

De acordo com o autor supracitado, para a Geografia interpretar o espaço humano como fato histórico precisa-se aliar a história mundial com a história local, isto é, não se pode querer explicar ou compreender determinado fato local sem compreender o contexto geral, pois dessa forma a base teórica se apresentará frágil e insustentável. O referido autor enfatiza também que as especificidades de cada lugar ajudam a compreender e a distinguir como cada formação socioespacial difere uma da outra. Para ele a história da humanidade é produzida e reproduzida nos espaços e nesses espaços são engendradas as diferentes formas, tanto material como imaterial que tendem expressar o pensamento social daquele momento, Santos (1979).

Desta forma, utilizando o conceito de formação Socioespacial, trabalhado por Santos (1979), tornase possível o entendimento da formação do município de Igarapé-Miri como produto de processos sociais históricos relacionados, em grande parte, a forças exógenas vinculadas ao modo de produção capitalista, desde o início do século XVIII aos dias atuais, mas que também está ligada a processos de natureza endógena, peculiares ao local e que se constituíram em elementos que diferenciaram a formação desse espaço em relação a de outros que compõem o Baixo Tocantins, como os que se expressam na identidade natural da região, marcada pela estrutura hídrica e vegetal, bem como as territorialidades que o constituem e contribuem para a re-estruturação espacial, a exemplo dos caboclos ribeirinhos.

\section{AS ATIVIDADES ECONÔMICAS COMO ELEMENTOS DA FORMAÇÃO SOCIOESPACIAL E O NOVO SIGNIFICADO DE IGARAPÉ-MIRI NA REDE URBANA DO BAIXO TOCANTINS}

O Município de Igarapé-Miri está localizado na região do Baixo Tocantins. O primeiro povoado foi elevado à categoria de vila pela Lei de $\mathrm{n}^{\circ} 113$, no dia 16 de outubro de 1843 , o qual recebeu o nome de Villa de Sant'Anna do Igarapé-Miri, mas apenas no dia 26 de julho de 1845, dois anos depois foi que essa Lei passou vigorar, devido às exigências do governador. Em 1896, pela Lei 438 de 23 de maio, Igarapé-Miri foi elevada à categoria de cidade (LOBATO, 2007). A origem do nome da cidade vem da língua tupi-guarani e significa: "caminho de canoa pequena" ou "pequeno caminho de canoas". O termo gentílico para quem nasce em Igarapé-Miri é igarapemiriense, embora a maioria da população prefira utilizar o termo miriense. A sua extensão territorial é de 1.996,790 km² e conta com uma população estimada em 62.698 (IBGE, 2017). A população está bem distribuída entre as áreas urbana e rural, na área urbana vive cerca de 45,12\% da população, já na zona rural 54,88\%. Sobre a densidade demográfica do Município tem-se 30,05 hab/km² (ANUÁRIO DO PARÁ, 2014; 2015). 
No mapa da Figura 1 pode-se observar o recorte empírico estudado, representado pelo município de Igarapé-Miri (na cor verde), com destaque para a sua sede (na cor laranjada), a rede hidrográfica do Baixo-Tocantins (na cor azul), a rede rodoviária (linhas vermelhas), bem como os municípios fronteiriços: Abaetetuba ao norte, Cametá ao sul, Moju a leste e Limoeiro do Ajuru a oeste. A distância entre Igarapé-Miri e a capital Belém é de 123 km (ANUÁRIO DO PARÁ, 2014; 2015).

Figura 1. Igarapé-Miri no Baixo Tocantins

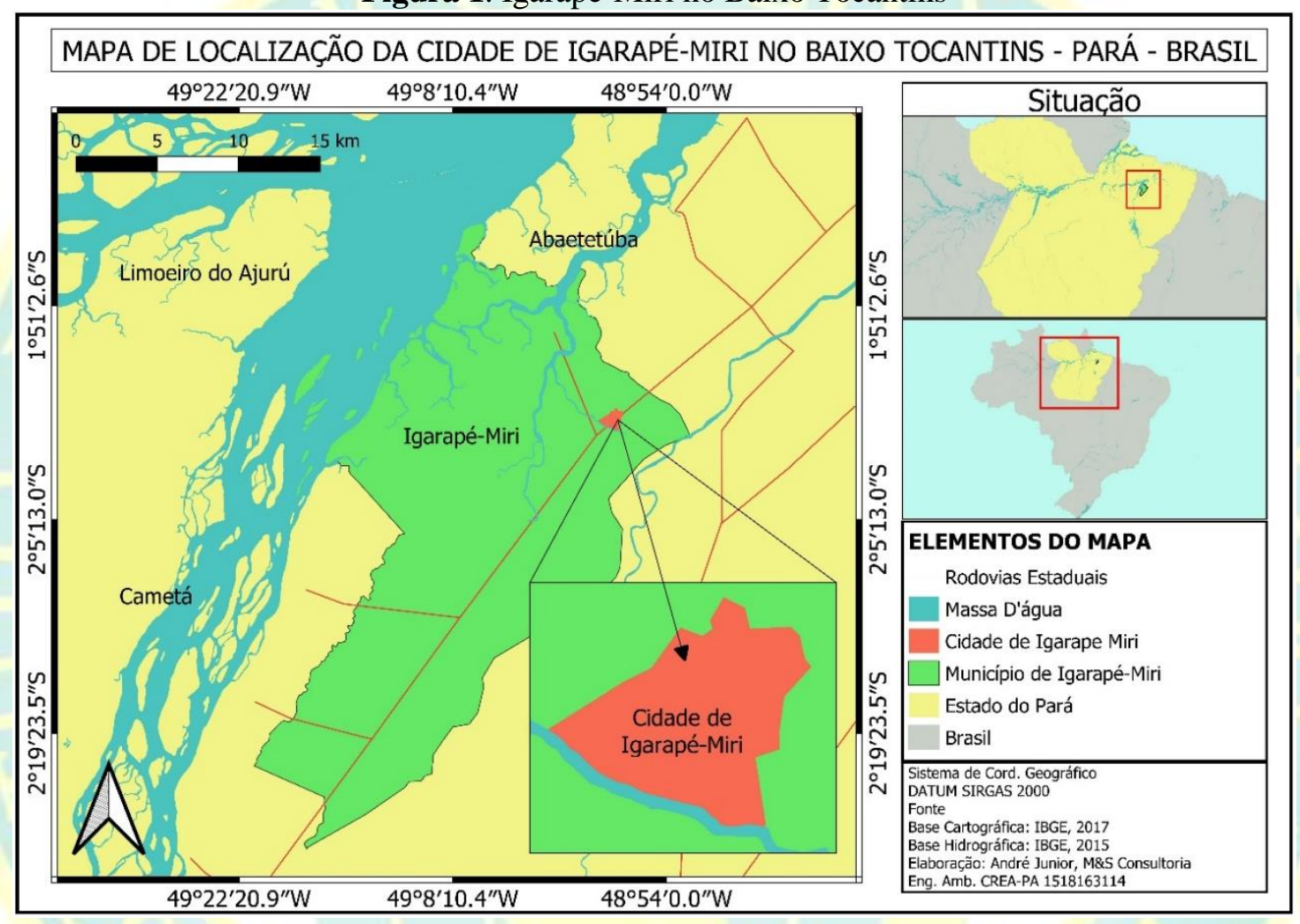

Fonte: Projeto cartográfico de Ederson Lobo. Execução André Junior (2020).

Para Becker (2006) a compreensão do novo lugar da Amazônia no espaço mundial e nacional exige uma breve análise da sua formação. Assim, percebe-se que não há como compreender a Amazônia hoje, sem que haja um entendimento histórico do processo de formação das cidades que compõe essa região. Durante os séculos XVII e XVIII os portugueses criaram estratégias geopolíticas que refletiram na configuração da Amazônia atual e, especificamente, na região conhecida atualmente como Baixo Tocantins.

Em seus estudos, Tavares (2007) apresenta três fatores ou momentos importantes para a consolidação e formação do território amazônico: o primeiro foi o da ação militar, em que os portugueses construíram fortificações nas embocaduras do rio Amazonas e seus afluentes com o objetivo de proteger o território contra a invasão de outros povos; o segundo foi marcado pela ação da igreja católica, com a chegada das ordens religiosas como as carmelitas, franciscanos, mercedários e jesuítas, responsáveis por catequizar os nativos e evitar conflitos de jurisdição por meio do controle ideológico; e o terceiro foi 
marcado pelas estratégias do Marques de Pombal que visaram garantir a posse e povoamento do território através da implantação de vilas que receberam a denominação de cidades portuguesas.

Na política de Pombal, a doação das sesmarias, a criação de vilas e cidades continuaram sendo formas que os portugueses encontraram para exercer posse e controle sobre a colônia. É dentro desse contexto que surgem os primeiros relatos sobre a formação e uso do espaço geográfico em Igarapé-Miri, através da doação de terras que os portugueses procuraram assegurar nessa área, onde hoje se encontra o Município. De acordo com Oliveira (1899), em outubro de 1710 o governador da Província do Maranhão e Grão-Pará, na época o Capitão General do Maranhão, Christovão da Costa Freire concedeu a um português, chamado João de Mello Gusmão uma Sesmaria com duas léguas de terra tendo com limite o Igarapé Cataiandeua (conhecido hoje pela maioria dos mirienses como Igarapé da Maromba) e o Rio Santo Antônio. Na Figura 2, o espaço da sesmaria concedido pelo então governador da província do Maranhão e Grão-Pará, delimitado pelo rio Igarapé-Mirí a sudoeste, o rio Santo Antônio a noroeste (na cor vermelha) e o igarapé Cataiandeua a leste (na cor azul).

Figura 2. Sesmaria concedida a João de Melo Gusmão no início do século XVIII

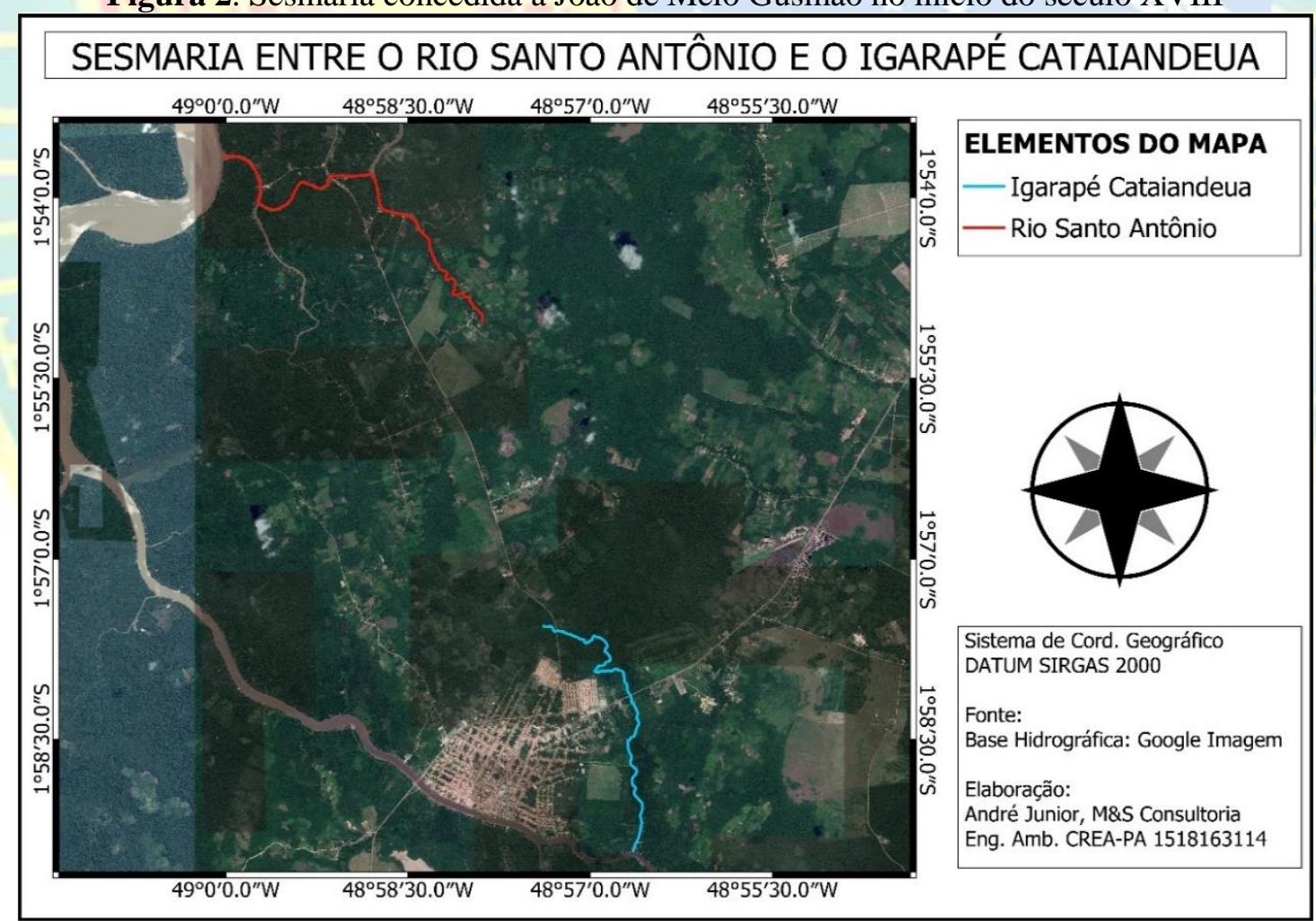

Fonte: Projeto cartográfico de Ederson Lobo. Execução André Junior (2020).

Segundo oliveira (1899) existem evidências da existência de uma madeireira denominada de "A Nacional", bem como comerciantes, agricultores e outras pessoas que habitaram aquela área antes da concessão das terras a João de melo Gusmão. E é a partir dessas evidencias que se inicia a análise da formação socioespacial sob a influência das atividades econômicas na região apoiado nas ideias de Santos; Silveira (2008) que afirmam que o importante é discutir, então, o território usado, sinônimo de espaço 
geográfico. Assim, o início do século XVIII é o momento em que o espaço territorial miriense sofreu modificações significativas devido à chegada de João de Mello Gusmão, a atividade extrativista da madeira realizada pela fábrica nacional e com a montagem do primeiro engenho de cana de açúcar.

Ao falar da formação socioespacial do Baixo Tocantins, Pereira (2014) deixa claro que essa estrutura territorial passou por alguns períodos marcados pelo desenvolvimento de atividades econômicas (como a exploração das drogas do sertão, cacau, cachaça, farinha) que foram decisivas para a estruturação e reestruturação dos espaços e a configuração diferenciada das paisagens. Com base nessa noção de formação socioespacial do autor supracitado, busca-se relacionar o presente artigo a um instrumento teórico capaz de proporcionar o entendimento sobre a formação socioespacial em uma escala espacial menor, em especifico do município de Igarapé-Miri, tomando como base alguns fatores de ordem econômica, como o desenvolvimento de atividades peculiares ao seu território, como o extrativismo da madeira, a agricultura da cana e o cultivo do açaí.

A investigação com apresentação das transformações que ocorreram no território miriense, sob as influências das atividades econômicas, aconteceu por meio de análise de cada período e dos episódios relevantes na formação do território. Sendo assim, a pesquisa coletou informações a respeito de cinco períodos, organizados da seguinte forma: Primeiro período da exploração da madeira (início do século XVIII); período da exploração da cana e produção do açúcar (meados do século XVIII ao final do século XIX); período da produção da cachaça (de 1920 a 1970); o segundo período da exploração da madeira (de 1950 a 1980); o período da expansão da produção e comercialização do açaí (de 2000 até os dias atuais).

A exploração da madeira foi a primeira atividade econômica de grande expressão no espaço onde se encontra o município de Igarapé-Miri e repercutiu de forma primária em seu processo de formação socioespacial. De acordo com Menezes; Guerra (1998), no século XVIII existia uma intensa atividade de exploração de madeira na região que hoje se chama de Baixo Tocantins, baseada na utilização da mão de obra escrava indígena e voltada para atender ao mercado europeu em pleno desenvolvimento. Sete fábricas reais localizavam-se nas margens de rios que batizaram as povoações de índios e colonos no período colonial. Entre essas povoações podem ser citadas as do Moju, Cametá, Igarapé-Miri, Abaetetuba, Acará, Barcarena, Conde, Baião e Beja. Igarapé-Miri se destacava na época por ser um espaço de grande exploração de madeira de qualidade, como o Piquiá e Angelim, espécies muito utilizadas como matéria prima na indústria naval portuguesa, fato reforçado na citação abaixo:

Como extensão dessa instituição surgiram as fábricas reais de madeira do vale do Tocantins, que forneciam a matéria prima para o arsenal do Pará e para exportação. A fragata Carolina, que serviu de apoio para a frota que transportou a família real portuguesa para o Brasil, em 1808, teria sido construída com madeira proveniente da fábrica real de madeira de Igarapé-Miri, que pertencia a coroa portuguesa, sendo um suporte do arsenal real da marinha portuguesa (MENEZES; GUERRA,1998).

Segundo Oliveira (1899), no lugar onde foi erguida a cidade de Igarapé-Miri, existiu a Fábrica Nacional para aparelhamento e que de lá eram exportadas para Belém, em abundância e das melhores qualidades. De lá a madeira era embarcada nos barcos e levada através dos rios para Belém, a sede provincial 
na época. Reafirmando o mesmo aspecto sobre essa pesquisa, Ferreira (1957 apud LOBATO; SOARES, 2001), enfatiza que das fábricas existentes na província do Grão-Pará, a Nacional era a mais proveitosa e de qualidade reconhecida. Araújo (2015) ressalta também sobre a importância dessa atividade econômica ao dizer que a fábrica existente em Igarapé-Miri pertencia a um complexo de fábricas da coroa portuguesa existente por toda a província do Maranhão e Grão-Pará e que de todas as fábricas existentes nessa região, a de Igarapé-Miri era a que mais produzia.

Durante muito tempo a Fábrica Nacional foi de grande importância para a economia e para o povoamento local. Nesse momento, o território começou a ser habitado e usado por inúmeras pessoas que emigraram em direção ao espaço que já não era mais o mesmo, iniciando relações sociais e econômicas que não existiam antes (OLIVEIRA, 1899). O povoamento do território exigiu uma nova organização espacial e logo implicou na construção social das paisagens. Através das experiências coletivas compartilhadas, não só o território miriense sofreu transformações como também os hábitos das pessoas se modificaram em decorrência das novas experiências e convívio. Como consequência do extrativismo madeireiro começou a surgir áreas desmatadas e campos, possibilitando o cultivo de inúmeras espécies de vegetais, algumas para atender as necessidades alimentares dos habitantes, enquanto outras espécies eram cultivadas para a comercialização, como foi o caso da cana-de-açúcar.

A segunda atividade econômica de destaque na formação socioespacial de Igarapé-Miri foi o cultivo da cana de açúcar. De acordo com Oliveira (1899), foi instalado no ano de 1712 o primeiro engenho para processar a cana e recebeu o nome de engenho Santa Cruz, movido à água oriunda de uma represa criada no igarapé Calha, no Rio Panacauera. No lugar onde era o engenho Santa Cruz hoje está a escola de Ensino Municipal Graziela Gabriel (LOBATO, 2007). Após a implantação do engenho Santa Cruz, outros também foram inseridos. Os engenhos tiveram dois momentos importantes na economia miriense, o primeiro foi com a produção do açúcar nos séculos XVIII e XIX e o segundo momento se deu com a produção da cachaça no século XX, entre as décadas de 1920 e 1970, após a crise nas exportações do açúcar brasileiro em função da concorrência sofrida em relação à produção do açúcar nas Antilhas e o fim do tráfico negreiro no final do século XIX (LIMA; PEREIRA, 2015).

Anderson (1991) reforça a ideia acima ao afirmar que essa atividade se constituiu na base da economia de Igarapé-Miri e Abaetetuba durante mais de dois séculos (a partir do século XVIII até a segunda metade do século XX), onde foi desenvolvido um sistema agroindustrial dedicado ao cultivo de cana e produção do açúcar (até o início do século $\mathrm{XX}$ ) e, principalmente, para a fabricação de aguardente em pequenos engenhos (no século XX). Para se ter ideia da importância da agroindústria do açúcar na economia desses municípios, na época do auge, na década de 1970, existiam cerca de 60 engenhos funcionando ao longo de vários rios dos municípios. Até a década de 1950 eram apenas 30. A área plantada dos municípios de Igarapé-Miri e Abaetetuba representavam mais de $90 \%$ da área plantada em cana-de-açúcar em todo o Estado do Pará (IBGE 1970a, p. 264). A produção de aguardente correspondeu a $100 \%$ da produção registrada em toda Amazônia (IBGE 1970b, p. 272-73). O valor da cana-de-açúcar produzida nestes dois 
municípios representou mais de $80 \%$ da renda das atividades agrícolas que empregaram a população nas suas extensas várzeas (IBGE 1970a).

A imagem da Figura 3 mostra a distribuição dos engenhos de cana de açúcar ao longo das áreas ribeirinhas dos municípios de Igarapé-Miri e Abaetetuba. Os círculos em branco representam os engenhos que funcionaram de 1960 a 1975. Já os círculos pretos correspondem os engenhos que estavam em atividade até 1987.

Figura 3. Engenhos de cachaça ao longo da rede hidrográfica nos municípios de Igarapé-Miri e Abaetetuba

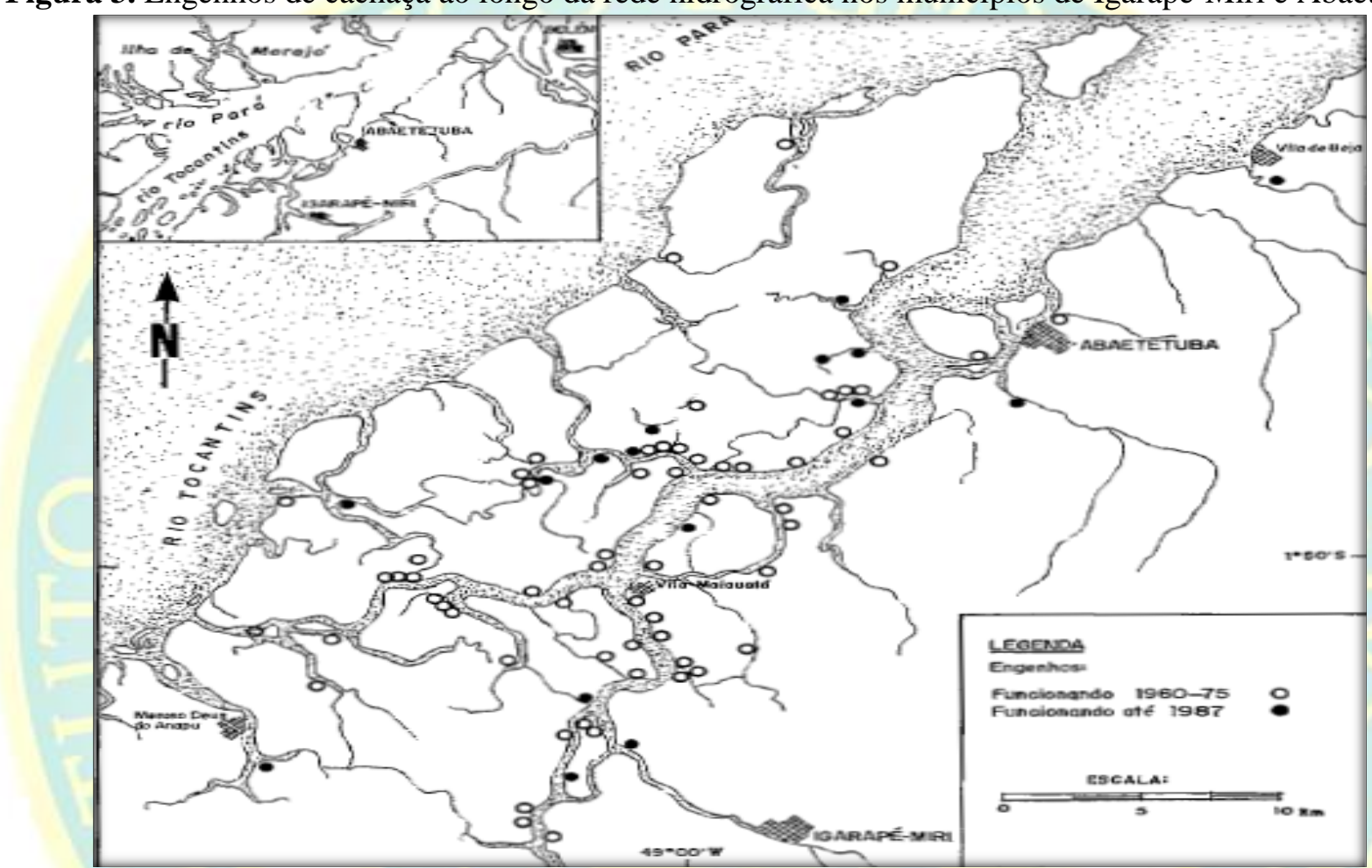

Fonte: ANDERSON (1991).

Quando se trata de Igarapé-Miri, o número de engenhos cresceu consideravelmente entre as décadas de 1940 e 1960, se espalhando pelo território do município. Segundo Lobato (2007, p. 101), "No final da década de 60 Igarapé-Miri contava com quarenta e nove engenhos em funcionamento, em atividades e riquezas (...)". Na Tabela 01, os nomes dos engenhos, dos seus respectivos donos e dos rios onde se situavam. 
Tabela 1. Engenhos, donos e rios em que se localizam.

Fonte: Elaboração da tabela com base em SANTIAGO (2013, p. 134 - 135).

\begin{tabular}{|c|c|c|c|}
\hline $\mathrm{N}^{\mathrm{o}}$ & NOMEDO ENGENHO & PROPRIETÁRIO & LOCALIZAÇÃO \\
\hline 01 & $\mathrm{~N}^{\mathrm{a}} \cdot \mathrm{S}^{\mathrm{a}}$ do Carmo & |--------------------- & Rio Igarapé-Miri \\
\hline 02 & Cacoal & André Pinheiro & Rio Igarapé-Miri \\
\hline 03 & São Paulo & José Araújo & Rio Meruú/Espera \\
\hline 04 & São João & Raimundo Costa & Rio Meruú \\
\hline 05 & Brasil & Julião S. Oliveira & S. Antônio \\
\hline 06 & Pará & Caetano C. Leão & Rio S. Antônio \\
\hline 07 & Recreio & Acácio C Leão & Rio S. Antônio \\
\hline 08 & Novo Horizonte & João F da Costa & Rio Meruú \\
\hline 09 & Jarí & Anilo M. Cardoso & Rio Japuretê \\
\hline 10 & Indiano & Plácido Nonato & Rio Meruú \\
\hline 11 & Livramento & Eládio Lobato & Rio Maiuatá \\
\hline 12 & Ariranha & Joaquim V. Bastos & Rio Itamimbuca \\
\hline 13 & São José & Raimundo M. de Lima & Furo do Seco \\
\hline 14 & Juarimbú & Joana Fortes & Rio Juarimbú \\
\hline 15 & São Luiz & Luiz Quintino & Ilha do Uruá \\
\hline 16 & São Jorge & Agenor Martins & Rio Meruú \\
\hline 17 & São João & João Quintino & Rio Maiuatá \\
\hline 18 & Santa Cruz & Alvez V.\& Cia & Rio Panacauera \\
\hline 19 & Ponta Negra & Rufino C. Leão & Rio Anapú \\
\hline 20 & Cariá & Silvestre C. Miranda & Rio Meruú \\
\hline 21 & São Raimundo & Raimundo M. de Souza & Rio Murutipucú \\
\hline 22 & São Domingos & Com. Acathauassú & Rio Maiuatá \\
\hline 23 & São Sebastião & Maciminano & Rio Juarimbú \\
\hline 24 & São Raimundo & Alcides Sampaio & Igarapé Santana \\
\hline 25 & São Benedito & Ricardo & Rio Meruú/Caiá \\
\hline 26 & São Raimundo & Didi machado & Rio Murutipucú \\
\hline 27 & Santa Helena & Miguel Belo & Rio Meruú \\
\hline 28 & Menino Deus & Antenor Sampaio & Rio Meruú \\
\hline 29 & Aliança & Irmãos Corrêa & Rio Murutipucú \\
\hline 30 & Conceição & Joaquim Português & Rio Piquiarana \\
\hline 31 & Nazaré & Meneleu Leão & Rio Maiuatá \\
\hline 32 & Santa Mario & Altino Sampaio & Rio Maiuatá \\
\hline 33 & Santa Luzia & Manduca Martins & Rio Igarapé-Miri \\
\hline 34 & Casa Vale & João Cametá & Pindobal \\
\hline 35 & São Raimundo & Izidório Quaresma & Rio Mamangal \\
\hline 36 & Trap. Hipólito & Sampainhos & Rio Maiuatá \\
\hline 37 & Veneza & Aladim Sampaio & Rio Meruú \\
\hline 38 & Fortaleza & Duquinha Lobato & Rio Maiuatá \\
\hline 39 & Liderança & Jerônimo Rodrigues & Rio Murutipucú \\
\hline 40 & São J. Tadeu & Arcelino Corrêa & Rio Murutipucú \\
\hline 41 & São Vicente & Praxedes V. Sousa & Rio Meruú \\
\hline 42 & Santo Antônio & Alacy Sampaio & Rio Maiuatá \\
\hline 43 & Vera Cruz & Maroca Fortes & Rio Panacauera-Miri \\
\hline 44 & Santo Antônio Botelho & Jango Miranda & Rio Maiuatá \\
\hline 45 & Pacheco & Plácido C. da Silva & Rio São Domingos \\
\hline 46 & São João & João C. Paiva (João Boi) & Rio São Domingos Furo do Seco \\
\hline 47 & Santa Maria & José Garcia da Silva & Rio Maiuatá \\
\hline 48 & Juarimbú & Maximiliano Cardoso & Rio Juarembú \\
\hline 49 & São Raimundo & Paconhaum & Rio Panacauera \\
\hline
\end{tabular}


A chegada dos engenhos e a atividade econômica do açúcar (em um primeiro momento) e cachaça (em um segundo momento) foram fatores muito importantes para a economia e para a estruturação do território miriense. Lugares que antes eram inóspitos e com densas florestas passaram a sofrer consideráveis modificações paisagísticas com as instalações dos engenhos, construções de casas, surgimento das vilas, pequenas lavouras, caminhos, comércios, igrejas, etc., em decorrência do novo vetor de ocupação que desencadeou novas relações sociais em vários níveis e escalas (OLIVEIRA, 1899).

A seguir, na Figura 4, um objeto ou forma espacial muito comum às margens dos rios de IgarapéMiri entre os séculos XVIII e XX, o engenho de cana de açúcar no rio São Domingos (furo do seco), do proprietário Sr. João Paiva, conhecido popularmente na cidade de Igarapé-Miri como João Boi. Este se constituiu em fonte de trabalho e renda durante mais de dois séculos, elemento econômico que motivou a emigração e povoamento das áreas ribeirinhas do município.

Figura 4. Engenho de cana de açúcar em Igarapé-Miri

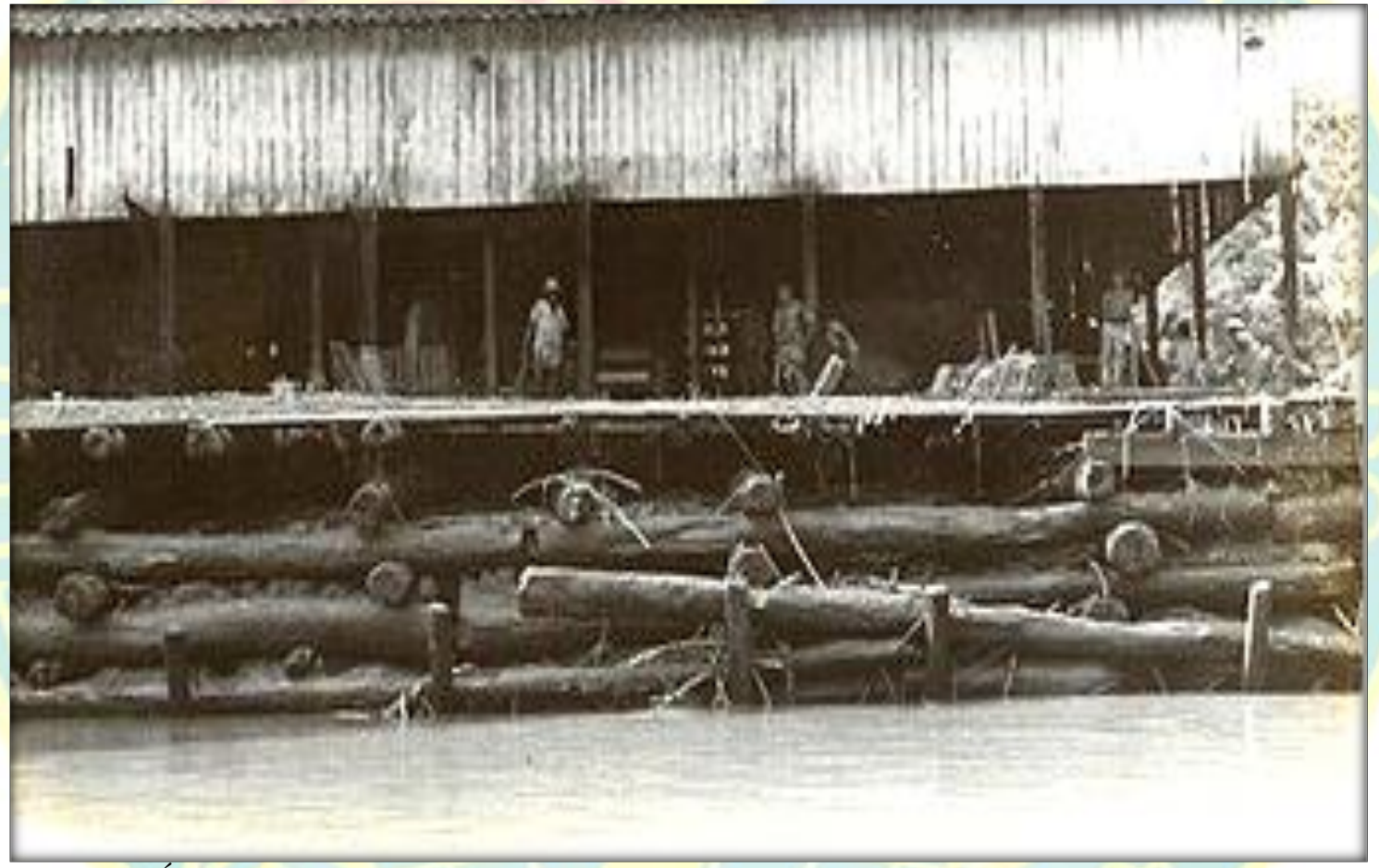

Fonte: ELÁDIO LOBATO (2007).

Sobre os acontecimentos e as mudanças espaciais do período de exploração da cana de açúcar, Lobato (2007) em seus estudos afirma que os numerosos engenhos espalhados por todo o município foram responsáveis pelo seu aumento demográfico, considerando que o mesmo chegou a ser o sétimo município em população do Estado do Pará e atualmente é o $17^{\circ}$. Percebe-se então que, em meados do século XX, IgarapéMiri tinha aumentado sua população e isso se deu, principalmente, pela numerosa quantidade de engenhos montados que passaram a atrair inúmeras famílias. Economicamente o período da cachaça foi de grande importância, uma vez que, segundo Lobato (2007), nos anos de 1938 e 1939, a coletoria de rendas federais de Igarapé-Miri, alcançou a renda máxima na região Norte do Brasil. 


\section{A formação socioespacial de Igarapé-Miri e seu atual significado na rede urbana do Baixo} Tocantins

A partir da década de 1970 a produção da aguardente entra em fase de declínio. Segundo Anderson (1991), alguns fatores foram decisivos para isso, como: a industrialização da cachaça no sul e sudeste; as interligações entre as regiões com a construção de estradas, a partir das políticas de JK, que provocaram a concorrência com a cachaça vinda dos outros centros produtores do sudeste e nordeste; a efetivação das leis trabalhistas; a produção adulterada realizada pelos atravessadores e a falta de políticas públicas voltadas para a melhoria e apoio técnico para a produção do produto em território miriense e abaetetubense.

Uma reportagem do Jornal Liberal no ano de 2000 reforça a afirmação supracitada ao afirmar que:

A pequena cidade, que em tempos de outrora era conhecida como a terra da cachaça, foi vítima dos tempos modernos. A abertura de estradas ligando o Pará ao Nordeste e ao Sul do Brasil e a nova política social de relação empregado-patrão foram decisivas para o fechamento de (quase) todos os engenhos, proporcionando mudanças radicais na economia do município (JORNAL "O LIBERAL", 23/07/2000, p. 4, apud LOBATO; SOARES, 2001).

A partir da década de 60 o município entra em um novo período de crescimento econômico que se estenderá até as décadas de 1980-90, novamente motivado pela extração da madeira. Esse recurso natural nunca deixou de ser explorado no município, mas durante os períodos econômicos do açúcar e da cachaça esse recurso não era a principal fonte econômica. À medida que os senhores de engenhos acumulavam capital, eles começaram a investir em outras atividades, como: olarias, comércios, barcos para viagens, lavouras e, principalmente, serrarias. Então, era comum naquela época notar ao lado dos grandes engenhos pequenas unidades voltadas para a serragem e beneficiamento da madeira. A partir da década de 1960 algumas dessas unidades se tornaram fortes e passaram a beneficiar grande quantidade de madeira, principalmente na zona urbana, onde três se destacaram: Indústria de Madeira Santos Ltda., a serraria Santana e a B Corrêa e Filhos. Essas unidades produtivas atraíram muitas pessoas da zona rural, se constituindo em fonte de emprego e renda, contribuindo para a configuração do espaço territorial na sede do município de Igarapé-Miri. ${ }^{4}$

Todas essas unidades de beneficiamento chamadas de serrarias foram importantes na dinâmica espacial do município, principalmente na zona urbana, por meio da construção de ruas, pontes, aterro de áreas, etc. Até a década de 1960 a prefeitura não possuía nenhum maquinário para abrir ruas ou aterrar, por isso, os proprietários dessas unidades de produção e beneficiamento faziam por conta própria. Os efeitos da crise econômica da chamada "década perdida" e a criação de leis ambientais mais rígidas foram fatores decisivos para o fechamento de muitas serrarias. No entanto, essa atividade nunca deixou de existir, pois até hoje algumas ainda se fazem presentes nas áreas de várzea e proximidades da cidade de forma mais tímida se comparado aos tempos que marcaram o final do século XX. A seguir, na Figura 5, a serraria do Sr. S. Corrêa, uma forma espacial marcante a beira do rio e em frente a cidade de Igarapé-Miri, responsável pela geração de empregos e renda, porém parte de um sistema degradante e comprometedor da floresta. ${ }^{5}$

\footnotetext{
${ }^{4}$ Relatos do senhor Obadias Pimentel, morador antigo da cidade de Igarapé-Miri.

${ }^{5}$ Relatos do senhor Obadias Pimentel, morador antigo da cidade de igarapé-Miri.
} 
Figura 5. Serraria a beira do rio Igarapé-Miri.

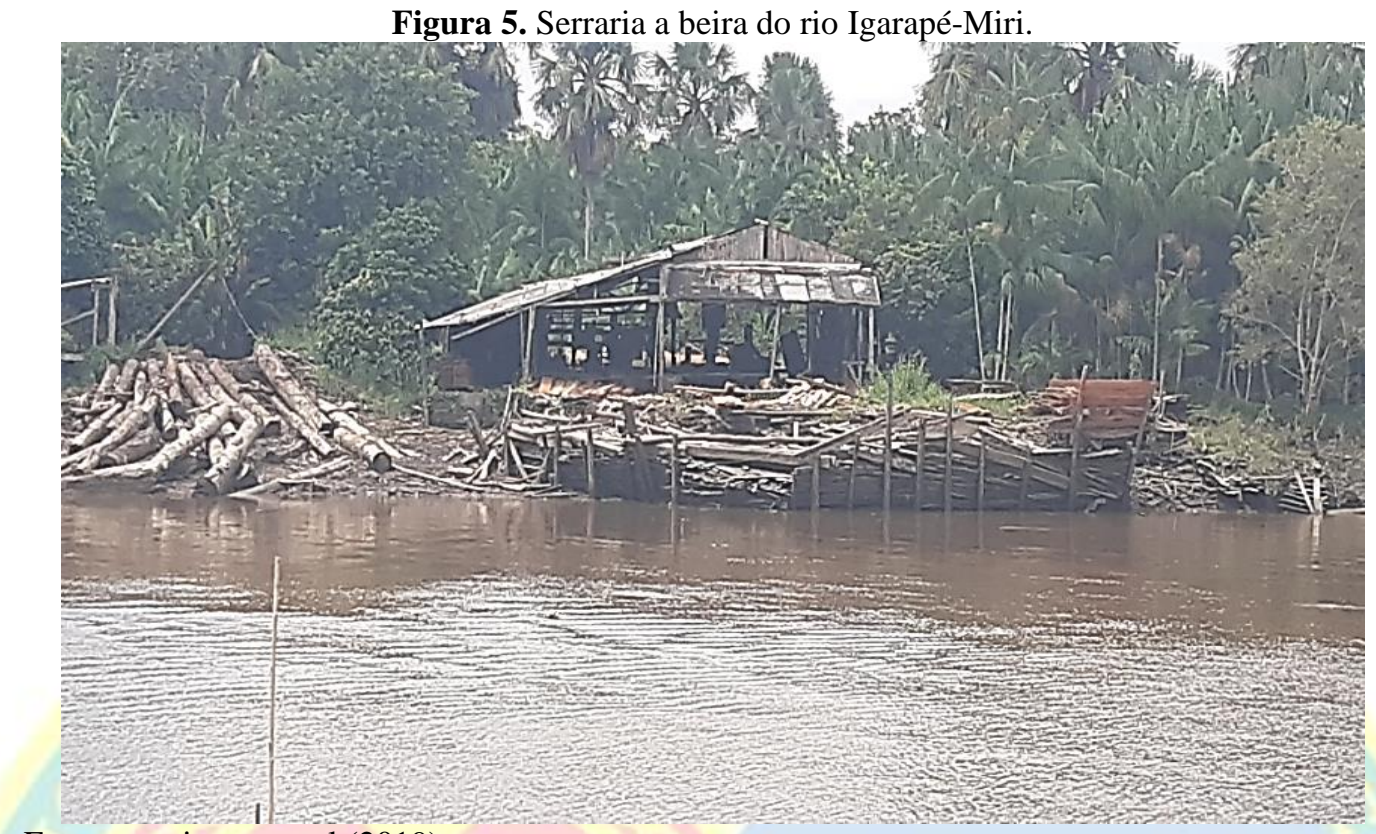

Fonte: arquivo pessoal (2019).

Com a decadência dos engenhos na década 1970 e das madeireiras na década de 1980, Igarapé-Miri experimentou nas décadas 1980 e 1990 um déficit muito acentuado na economia local associado a uma extrema miséria e vulnerabilidade social. Na busca de superar essa situação e de recuperar a economia miriense, passou a ser desenvolvido, mesmo de forma tímida, o extrativismo de palmito da palmeira do açaí. Apesar de não gerar renda significativa para o município, comparado aos períodos já mencionados, ao mesmo tempo criava-se um problema ambiental com as palmeiras cortadas para a extração do palmito utilizadas apenas uma única vez. Araújo (2015) afirma que a decadência da matriz industrial de fabricação de aguardente também abriu espaço para a instalação (em escala elevada) de unidades dedicadas ao beneficiamento de palmito em conserva, diga-se de passagem, a partir de matéria prima obtida de forma bastante predatória sob a ótica ambiental.

A década de 2000 marca o início do período econômico da expansão da produção e comercialização do açaí que se estende até os dias atuais. Hoje Igarapé-Miri é conhecida como "A capital mundial do açá'”, título proposto pelo historiador miriense João Maria Quaresma Júnior e utilizado pelo poder público e população local como representação simbólica e forma de expressar a grande produção alcançada ao logo desses últimos anos e que, segundo o IBGE, ultrapassou 305 mil toneladas em 2017, colocando o município em primeiro lugar na produção do açaí no Brasil. De acordo com Pará (2018) o valor da produção agrícola do país foi de 319,6 bilhões em 2017, sendo que o valor de produção na região norte foi de 22,6 bilhões. Mais da metade desse total, 12,8 bilhões vieram do Estado do Pará, em particular, de Igarapé-Miri-Pa, que tem no açaí 99,5 \% dos 1,8 bilhão arrecadados pelo município na produção agrícola.

Segundo o PAM IBGE de 2018 o município arrecadou 880 milhões de reais em rendimentos provenientes da venda do açaí. A Tabela 2 mostra a expressividade do município na produção agrícola, 
baseada na exploração do açaí, no ano mencionado, em que mais de noventa por cento do total arrecadado foi proveniente da produção deste produto.

Tabela 2. Valor da produção agrícola no Brasil, região norte, Pará e em igarapé-Miri. Ano 2017

\begin{tabular}{|c|c|}
\hline Brasil & 319,6 Bilhões de reais. \\
\hline Região norte & 22,6 Bilhões de reais. \\
\hline Pará & 12,8 Bilhões de reais. \\
\hline Igarapé-Miri. & 1,8 bilhões de reais. (Desse total, 880 milhões foram da cadeia produtiva do açaí) \\
\hline
\end{tabular}

Fonte: PAM-IBGE, 2018.

Os produtos derivados da exploração dos açaizais ocupam lugar de destaque na economia do Pará, pela produção de frutos e palmito, produtos comercializados tanto no próprio Estado como também vendido para outras regiões do país e para o exterior, contribuindo de forma significativa para a receita paraense. Pelo lado social, os frutos do açaizeiro são de fundamental importância para subsistência de muitas populações ribeirinhas pelo alimento que proporcionam e pelo excedente familiar.

A fruta do açaí por suas características próprias de cheiro, sabor, valor nutritivo, entre outros, estimulou sua venda para outras partes do país e exterior. De acordo com a secretaria de desenvolvimento e mineração do Estado do Pará - SEDEME, a produção total de açaí no Estado cresceu consistentemente e a exportação tem crescido $13 \%$ ao ano em média, com $90 \%$ da produção indo para os EUA e Japão. A demanda local no Estado é de 500 a 700 mil toneladas. A perspectiva é que em 2030 seja possível atingir uma produção de 1,5 milhões de toneladas, com 50 mil hectares adicionais plantados e melhor manejo nas várzeas. O melhoramento genético e pesquisa do cultivo de açaí favorecem a qualidade e produção.

A demanda crescente do mercado de polpa do açaí, induzido pelo processo de beneficiamento e congelamento quadruplicou o consumo mundial, antes restrito ao período de safra. Agora, no período da entressafra os plantios irrigados conseguem suprir a demanda anual de produção e do beneficiamento efetuado por batedeiras elétricas das grandes fábricas com suas modernas máquinas industriais de processamento dessa fruta (PARÁ, 2018).

Cerca de $20 \%$ do açaí in natura que é produzido destina-se ao consumo interno dos moradores e $80 \%$ destina-se às diversas agroindústrias de polpa do Pará e outros Estados ${ }^{6}$. Existem em Igarapé-Miri 08 agroindústrias que transformam o fruto do açaí em poupa, são elas: Açaí Miriense, Bony Açaí, Vale do Açaí, Açaí Vita Nat, Açaí Amazon, Sabor do Açaí, Nutre Latino e Dapancol. Segundo o Sr. Dario Júnior? proprietário da Dapancol, as fábricas chegam a produzir polpa durante 07 a 08 meses por ano (geralmente de agosto a fevereiro), conseguindo produzir volume mais expressivo nesse período.

A tabela 03 fornece alguns números relativos à produção de polpa em toneladas em cada agroindústria do município. Os dados são referentes à produção da polpa do açaí nessas empresas na safra de

\footnotetext{
${ }^{6}$ Informação obtida através de entrevista com o dono da fábrica Dapancol, Sr. Dário Jr em 08/11/2018.

7 Informação obtida através de entrevista com o dono da fábrica Dapancol, Sr. Dário Jr em 08/11/2018.
} 
2018 e mostram que em todas o volume produzido ultrapassa 13 toneladas, com destaque para a Nutrilatino com 40 toneladas, Açaí Vita Nat com 40 toneladas e a Bony Açaí com 30 toneladas.

Tabela 3. Produção anual das agroindústrias de açaí que atuam em Igarapé-Miri

\begin{tabular}{|c|c|}
\hline EMPRESA & QUANTIDADE/ DIÁRIA EM POLPA \\
\hline Dapancol & 15 toneladas \\
\hline Açaí Vita Nat & 40 toneladas \\
\hline Vale do Açaí & 15 toneladas \\
\hline Açaí Miriense & 13 toneladas \\
\hline Nutrilatino & 40 toneladas \\
\hline Açaí Amazon & 15 toneladas \\
\hline Sabor do Açaí & 15 toneladas \\
\hline Bony Açaí & 30 toneladas \\
\hline TOTAL & $\mathbf{1 8 3}$ toneladas \\
\hline
\end{tabular}

Fonte: elaborada com base em entrevista com o proprietário da agroindústria Dapancol, SR Dário Jr. $(08 / 11 / 2018)$.

Igarapé-Miri exporta tanto a polpa quanto o fruto em caroço. O fruto em caroço, na grande maioria, é exportado para outras cidades dentro do próprio Estado do Pará, onde cidades como Castanhal, Marituba, Tomé-Açú e Benevides são as maiores compradoras. Sobre a quantidade de açaí in natura exportado no período da safra, todos os dias saem cerca de 50 caminhões carregados de Igarapé-Miri, cada um levando em média 600 basquetas $^{8}$ com 30 quilos. Se multiplicar o número de caminhões (50) pelo número de basquetas (600) chega-se a um total de 30.000 (trinta mil) basquetas que são exportadas todos os dias. Se considerarmos que cada uma tem capacidade para 30 quilos, então teremos um volume de 900 toneladas de açaí in natura que é vendido diariamente para outros municípios 9 .

Sobre a quantidade diária de açaí que se consome e que é transformado em polpa em Igarapé-Miri, além desses 50 caminhões que saem, outros 15 caminhões abastecem as agroindústrias de polpa do município e atendem à demanda de vários batedores autônomos da cidade que garantem o consumo interno. Se multiplicar o número de caminhões que abastecem as agroindústrias e o mercado interno (15) pelo número de basquetas (600) chega-se a um total de 9.000 basquetas. Se cada basqueta tem 30 quilos, então a

\footnotetext{
${ }^{8}$ Recipiente de plástico utilizado para o transporte do açaí in natura. Cada basqueta tem capacidade para 30 quilos de açaí in natura.

${ }^{9}$ Informações obtidas através de relatos em entrevista com o Sr Dario Jr, proprietário da agroindústria Dapancol. Entrevista em 08/11/2018.
} 
quantidade de açaí que fica na cidade para ser consumida diariamente pela agroindústria e população é de 270.000 quilos, ou 270 toneladas $^{10}$.

Uma basqueta, que equivale a 30 quilos, produz em média 20 quilos de polpa. Considerando que em Igarapé-Miri ficam 9.000 basquetas para o consumo interno e toda essa quantidade seja transformada em polpa, chega-se a um total de 180.000 quilos ou 18 toneladas de polpa por dia. As imagens abaixo indicam a localização das agroindústrias de polpa de açaí em Igarapé-Miri ${ }^{11}$. Na Figura 6, as agroindústrias localizadas na sede do município e na Figura 16, as agroindústrias localizadas na zona rural.

Figura 6. Agroindústrias de açaí na sede do município de Igarapé-Miri.

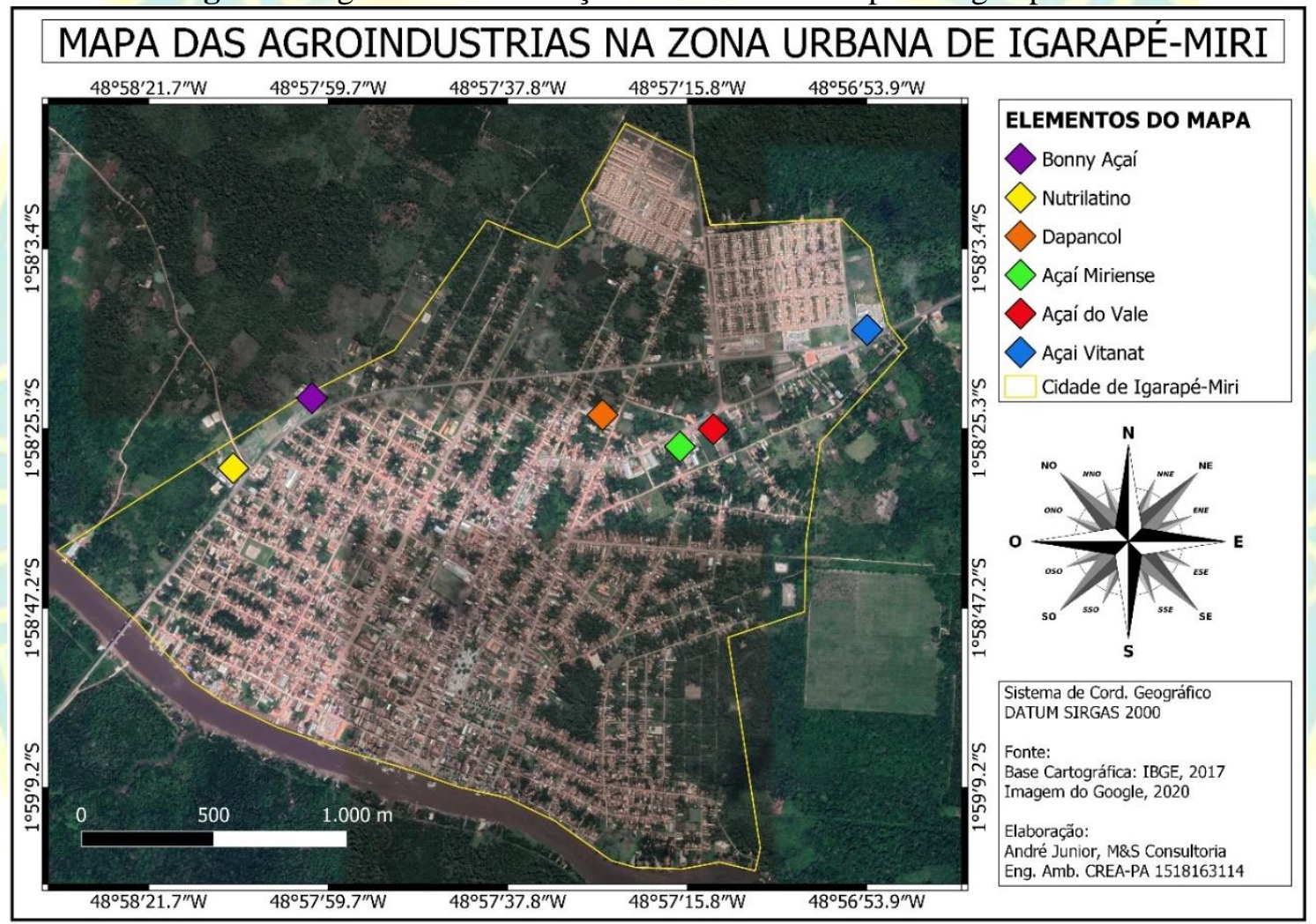

Fonte: projeto cartográfico Ederson Lobo, execução André Junior (2020).

Abaixo, as agroindústrias de açaí localizadas na zona rural

\footnotetext{
${ }^{10}$ Informações obtidas através de relatos em entrevista com o Sr Dario Jr, proprietário da agroindústria Dapancol. Entrevista em 08/11/2018.

${ }^{11}$ Informações obtidas através de relatos em entrevista com o Sr Dario Jr, proprietário da agroindústria Dapancol. Entrevista em 08/11/2018.
} 
Figura 7. Agroindústrias de polpa de açaí na zona rural.

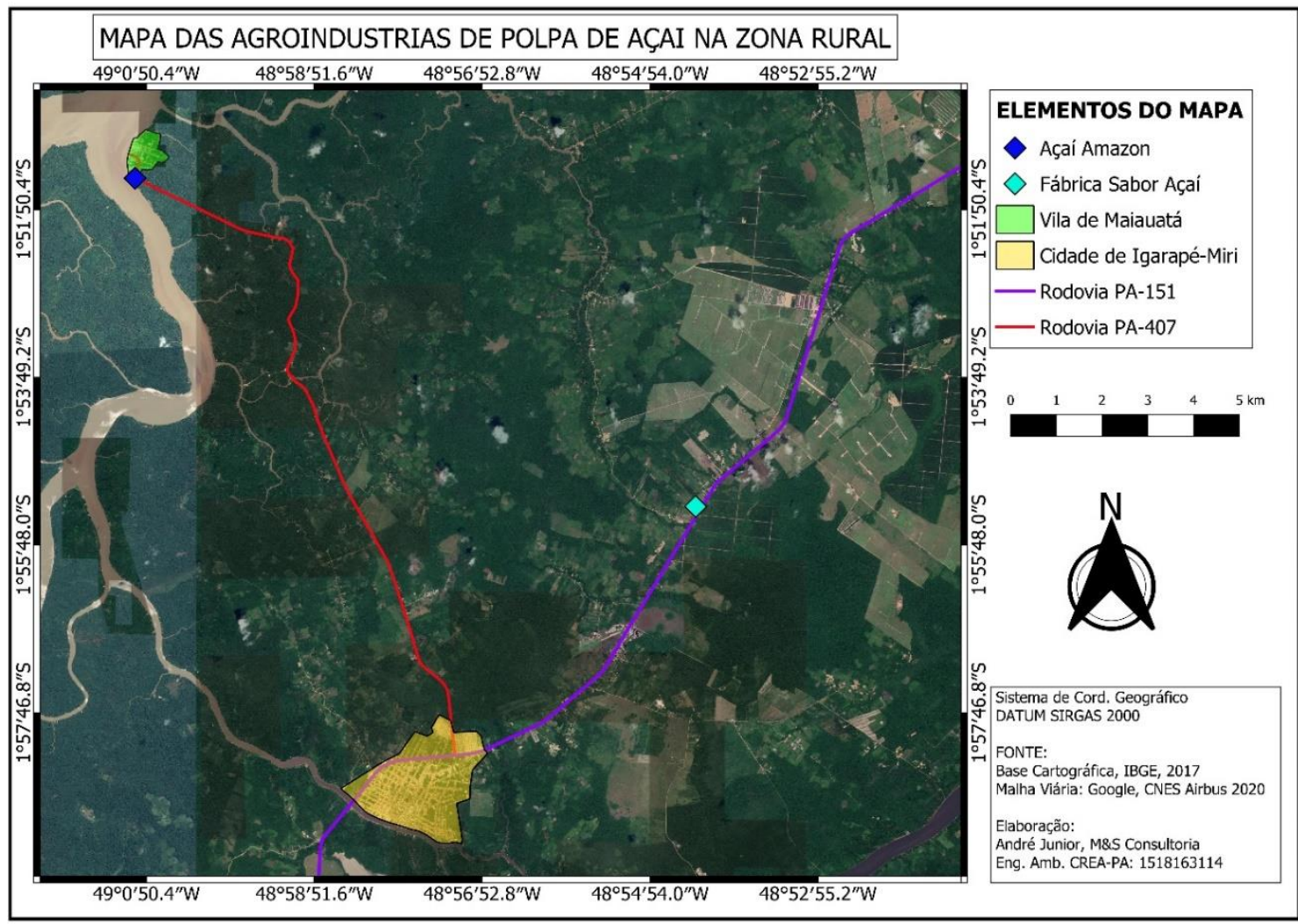

Fonte: projeto cartográfico Ederson Lobo, execução André Junior (2020).

Observa-se que no atual período econômico do açaí as indústrias estão localizadas tanto na zona rural (duas) como na urbana (seis), totalizando oito indústrias. De acordo com as pessoas entrevistadas, cada uma dessas indústrias que trabalham no beneficiamento do açaí chega a empregar em média entre de 30 a 50 pessoas. Se multiplicar essa quantia de pessoas pelo número de indústrias, chega-se, em média, a um total de 240 a 400 empregos diretos. Ainda há aqueles que trabalham para os donos de açaizais, como o peconheiro, carregadores, vigias, barqueiros, técnicos, além de batedores e tantos outros que sobrevivem da produção do açaí na zona urbana.

Da Silva e Amorim (2017), retratam de forma breve sobre a rotina diária de alguns agentes envolvidos na cadeia produtiva do açaí, como os peconheiros, os carregadores e batedores. Os peconheiros são pessoas que trabalham de segunda a sábado, em média 8 horas por dia, na extração do fruto do açaizeiro em áreas de várzea com a ajuda de faca e um utensílio utilizado nos pés para facilitar a subida na palmeira, chamado de peconha ${ }^{12}$. A maioria dos trabalhadores peconheiros é do mesmo rio ou de outro e geralmente ganham por cada rasa ${ }^{13}$ que enchem. Muitos começam a trabalhar dede os 15 anos e, dependendo do acordo com o proprietário, podem ganhar remuneração por dia ou semana.

\footnotetext{
${ }^{12}$ Utensilio em forma de círculo feito de saca de plástico, utilizado em volta dos pés para facilitar a subida nas palmeiras.

${ }^{13}$ Paneiro de fibra de miritizeiro, utilizado para o transporte do açaí in natura.
} 
Os peconheiros costumam subir sem proteção nos açaizeiros, que têm em média 15 metros de altura. Diante das condições precárias de trabalho, a atividade foi considerada uma das mais perigosas do Brasil, segundo pesquisa realizada pelo Instituto Peabiru, em parceria com o Tribunal Regional do Trabalho da $8^{\mathrm{a}}$ Região do Pará e Amapá (TRT8) (REVISTA ELETRÔNICA GLOBORURAL, 2018). Na figura 7, um peconheiro em seu trabalho diário de coleta do açaí em cachos, munido de instrumentos essenciais, que o auxiliam em sua rotina de subida nas palmeiras do açaizal.

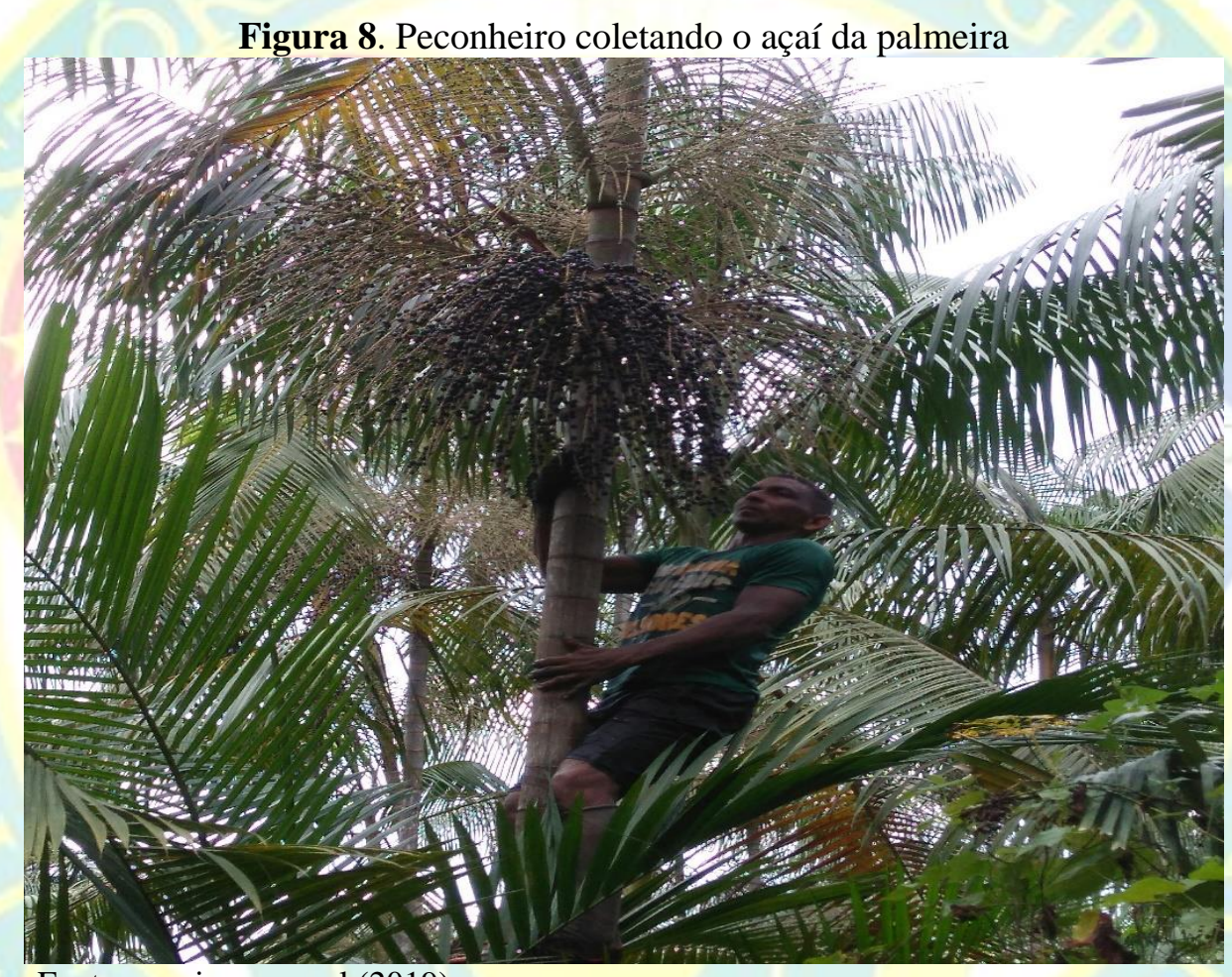

Fonte: arquivo pessoal (2019).

Os carregadores de açaí são trabalhadores responsáveis pelo abastecimento de barcos e caminhões. O tempo de trabalho é, geralmente, de 8 horas por dia, de segunda a sábado. A maioria dos carregadores trabalha como forma de acordo informal (nada por escrito e sim verbalmente). O dono do caminhão, precisando de carregadores, conversa com algumas pessoas que estão habilitadas para trabalhar, e assim cada uma recebe um valor específico por cada rasa carregada. O período do trabalho geralmente é nos turnos da tarde e noite, iniciando às 17 horas e se estendendo, muitas vezes, até as 5 horas da manhã. Os caminhões carregados do fruto se dirigem para pontos de beneficiamento de Igarapé-Miri e, principalmente para outras cidades como Castanhal, onde é transformado em polpa e comercializado para outros mercados.

Os batedores de açaí são trabalhadores que geralmente acordam na madrugada para comprar o fruto in natura e, ao longo do dia, transformam a polpa em líquido em suas máquinas batedeiras para vender e atender a grande demanda da população da cidade. A maioria trabalha a partir das 7 até 22 horas, de segunda a domingo, abastecendo as mesas das famílias mirienses. De acordo com o departamento de vigilância sanitária de Igarapé-Miri, existem 280 estabelecimentos com máquinas batedeiras cadastradas que produzem 


\section{A formação socioespacial de Igarapé-Miri e seu atual significado na rede urbana do Baixo}

Tocantins

o vinho ou suco de açaí na cidade. Esses estabelecimentos funcionam em média com quatro trabalhadores (totalizando, aproximadamente, 1.120 trabalhadores de estabelecimentos cadastrados) que, na maioria dos casos, utilizam esse trabalho como fonte de renda para o seu sustento e de suas famílias. A seguir, na tabela 03, um demonstrativo da quantidade de estabelecimentos cadastrados de batedeiras de açaí distribuídas pelos bairros da cidade de Igarapé-Miri e em duas importantes vilas do município.

Tabela 4. Número e distribuição de batedeiras de açaí nos bairros da cidade.

\begin{tabular}{|c|c|}
\hline Boa esperança & 33 Cadastrados \\
\hline Centro & 45 Cadastrados \\
\hline Matinha & 20 Cadastrados \\
\hline Cidade nova & 80 Cadastrados \\
\hline Santa Clara & 10 Cadastrados \\
\hline São Paulo & 15 Cadastrados \\
\hline Capadócia (Condomínio Açaí lar) & 04 Cadastrados \\
\hline Vila Maiauatá & 42 Cadastrados \\
\hline Vila Icatú & 31 Cadastrados \\
\hline
\end{tabular}

Fonte: DEPARTAMENTO DE VIGILÂNCIA SANITÁRIA DE IGARAPÉ-MIRI (2019).

Analisando o quadro acima percebe-se o quanto a atividade dos batedores de açaí é expressiva na cidade e em algumas vilas (considerando que existem também muitos batedores não-cadastrados), onde servem de fonte de trabalho e renda. O quadro também deixa explicito em quais bairros e vilas essa atividade se faz mais presente, como nos bairros da cidade nova e centro e na vila Maiauatá. A maior parte do açaí que chega à cidade para a venda, algo em torno de $90 \%$, é proveniente de distritos das áreas de várzeas. Os principais distritos localizam-se nos rios Meruú, Anapú, Panacauera, Igarapé-Miri Velho, Canal, Igarapézinho, Cají, Pindobal, entre outros (DA SILVA; AMORIM, 2017). Além dos que trabalham nos açaizais, a cadeia produtiva do açaí também envolve outros agentes como transportadores, atravessadores, indústrias de beneficiamento e os batedores artesanais que além de contribuírem para a geração de renda de expressivo grupo de famílias na cidade, trabalham diariamente para que o vinho do açaí possa chegar à mesa da população miriense.

Diante disso, observa-se que as transformações socioespaciais que deram uma nova configuração ao espaço territorial de Igarapé-Miri a partir da década de 2000, ocorreram tanto na zona rural como na zona urbana, sendo, em grande parte, reflexo de processos históricos que acabaram determinando as relações e ações sociais sobre o espaço no presente. Tais mudanças socioespaciais derivaram de fatores que assumiram caráter, principalmente econômico, imputando ao território diferentes significados de acordo com a utilização e desenvolvimento de atividades econômicas ao longo do tempo e sobre o espaço. Para facilitar o entendimento a respeito dos processos que provocaram a formação socioespacial de Igarapé-Miri, elaborouse a tabela 5, uma síntese mostrando os fatores ou elementos que contribuíram para a formação socioespacial em diferentes contextos e que determinaram seu significado atual na divisão territorial do trabalho do baixo Tocantins. 
Tabela 5. Fatores da formação socioespacial de Igarapé-Miri em diferentes contextos.

\begin{tabular}{|c|c|c|}
\hline $\begin{array}{c}\text { Fatores da formação } \\
\text { socioespacial. }\end{array}$ & Período/Contexto & Implicações socioespaciais. \\
\hline $\begin{array}{l}\text { - Ocupação e } \\
\text { exploração portuguesa. }\end{array}$ & - Início do século XVIII (1710). & $\begin{array}{l}\text { - Origem e formação territorial. } \\
\text { - Desenvolvimento de atividade } \\
\text { madeireira (Fábrica nacional). } \\
\text { - Início do povoamento. } \\
\text { - Surgimento da primeira vila. }\end{array}$ \\
\hline $\begin{array}{l}\text { - A ação da Igreja } \\
\text { católica. }\end{array}$ & - Início do século XVIII. & $\begin{array}{l}\text { - Aldeamentos e missões } \\
\text { religiosas. } \\
\text { - Construção da capela e Igreja } \\
\text { de Santana. } \\
\text { - Estruturação do largo de } \\
\text { Santana. } \\
\text { - Povoamento e consolidação } \\
\text { do território. }\end{array}$ \\
\hline $\begin{array}{l}\text { - Desenvolvimento de } \\
\text { atividades econômicas. }\end{array}$ & $\begin{array}{l}\text { - Século XVIII (atividade } \\
\text { madeireira). } \\
\text { - Século XVIII ao Século XX } \\
\text { (produção da cana de açúcar e } \\
\text { derivados: açúcar e cachaça). } \\
\text { - Século XX (atividade } \\
\text { madeireira). } \\
\text { - Século XXI (produção do } \\
\text { açaí). }\end{array}$ & $\begin{array}{l}\text { - Serrarias e povoamento ao } \\
\text { longo dos rios. } \\
\text { - Surgimento de vilas. } \\
\text { - Engenhos e povoamento ao } \\
\text { longo dos rios. } \\
\text { - Intensificação do povoamento } \\
\text { na sede com o ressurgimento da } \\
\text { atividade madeireira. } \\
\text { - Fixação de pessoas na zona } \\
\text { rural (extrativismo do açaí). } \\
\text { - Melhoria das condições de } \\
\text { vida. } \\
\text { - Reestruturação espacial rural e } \\
\text { urbana. }\end{array}$ \\
\hline
\end{tabular}

Fonte: ELABORADO POR EDERSON LOBO, COM BASE EM PESQUISA BIBLIOGRÁFICA. (2018).

Na tabela 5 pode-se observar, de forma resumida, as informações prestadas ao longo do artigo, delimitando cada período e acontecimentos que desencadearam a formação socioespacial de Igarapé-Miri, desde o século XVIII até o século XXI, destacando ações políticas (como a concessão de terras-Sesmarias, pela coroa portuguesa), ações religiosas (como a estruturação do largo de Santana) e ações que motivaram o desenvolvimento de atividades econômicas no território, inserindo o município (com base em um significado ou papel econômico) na divisão territorial do trabalho de forma a obedecer, em cada período, uma lógica de produção vinculada a interesses inerentes ao modo de produção capitalista. Atualmente exerce novo significado na dinâmica econômica do Baixo Tocantins, estando inserido na divisão territorial do trabalho como maior produtor e exportador de açaí. Mas, não fugindo à regra, sua organização territorial do presente é reflexo de processos que marcaram e definiram a formação socioespacial ao longo de diversos períodos. 


\section{CONSIDERAÇÕES FINAIS}

Com o trabalho chegou-se ao entendimento de que o espaço é resultado direto das ações humanas com os elementos que o constituem e cada configuração ao longo do tempo é reflexo do modo de produção vigente, se constituindo em condição para a reprodução desse modo de produção. Mas é um produto que, ao mesmo tempo, intervém na reprodução desta sociedade, organizando o trabalho produtivo, as redes de distribuição, os fluxos de circulação, os lócus de consumo e de produção, etc. Desta forma, este produto é também, dialeticamente, produtor.

A pesquisa realizada contribuiu para se chegar às respostas das questões levantadas nesse artigo, proporcionando o conhecimento sobre formação socioespacial do município de Igarapé-Miri ao longo do tempo, associada ao uso do espaço para o desenvolvimento de atividades que foram o sustentáculo da economia do município em cada período mencionado. Assim, o tempo que vai do início do século XVIII até fim do século XX se constitui em um período marcado pela exploração da madeira; parte do século XVIII até o final do século XX, o período da exploração da cana de açúcar; e o início do século XXI, o período marcado pela expansão do extrativismo do açaí. Em todos esses períodos o espaço geográfico delimitado para estudo sofreu transformações decorrentes dos processos sociais que nele aconteceram, permitindo a reprodução social e novas formas de organização espacial.

Além disso, o trabalho deixa claro que Igarapé-Miri assumiu, no início do século XXI, um novo significado na divisão territorial do trabalho do Baixo Tocantins como grande produtor e exportador de açaí, fato que lhe confere o título de "A capital mundial do açaí". Esse novo significado se confirma e se justifica a partir do momento em que se verifica que o município estabelece relações e interação com outros espaços via economia do açaí, expressando centralidade marcante no espaço regional. Já o espaço municipal vem sofrendo, ao longo do tempo, processo de ocupação e transformação onde os agentes sempre estiveram associados, em menor ou maior grau de intensidade, a interesses externos voltados à reprodução do modo de produção capitalista. Foi assim nos períodos da produção da madeira e da cana de açúcar, e continua sendo assim no atual período de desenvolvimento da cadeia produtiva do açaí, pois se observa que o espaço de produção e circulação vem sendo cada vez mais utilizado e produzido conforme aos interesses de agentes ligados ao capital nacional, que por sua vez, estão ligados ao capital internacional, como as empresas de beneficiamento do açaí, os bancos, entre outras.

O título atribuído "A capital mundial do açaí" contribui para dar visibilidade econômica ao município nas escalas regional, nacional e até global, simboliza e dá sentido ao novo significado que o mesmo assume na região do Baixo Tocantins como maior produtor e exportador de açaí. Os números fornecidos pelas fontes citadas na pesquisa e mencionados ao longo do artigo confirmam e validam tal título. No entanto, embora a cadeia produtiva do açaí provoque certo crescimento econômico e mudanças na estrutura socioespacial, entende-se que ela deveria ser melhor explorada pelos órgãos de gestão pública no sentido de arrecadação tributária mais efetiva. Caso isso se tornasse realidade, os recursos obtidos com tal arrecadação poderiam servir como instrumento para a geração de mais benefícios e desenvolvimento social. 


\section{A formação socioespacial de Igarapé-Miri e seu atual significado na rede urbana do Baixo}

Tocantins

Portanto, pode-se dizer que os objetivos propostos no presente artigo foram atingidos satisfatoriamente. Quando, em um primeiro momento, se propôs discorrer sobre a formação socioespacial, deixou-se claro que o espaço é um produto social, e, ao mesmo tempo, produtor, que garante a reprodução da sociedade e do modo de produção capitalista. A coleta de dados e informações históricas em documentos, livros de autores que escreveram sobre Igarapé-Miri e trabalhos acadêmicos sobre a formação territorial desse município, bem como a utilização da periodização como recurso metodológico garantiram, em um segundo momento, os meios para a identificação e entendimento de sua base econômica desde sua origem no século XVIII até os dias atuais, quando o mesmo se destaca no contexto econômico local e está inserido no contexto regional e global como grande produtor e exportador de açaí.

As diferentes funções ou significados econômicos que o município assumiu no passado e no presente foram essenciais para o desenvolvimento do mesmo em cada período destacado. Além disso, os processos sociais inerentes a cada período, contribuíram para deixar marcas na paisagem, heranças socioespaciais que, até hoje, compõem e fazem parte da nova configuração espacial juntamente com as formas e objetos criados a partir do novo significado econômico do município, como grande produtor e exportador de açaí.

\section{REFERÊNCIAS}

ANDERSON. D. Scott. Engenhos na Várzea: Uma análise de declínio de um sistema de produção tradicional na Amazônia. IN: Amazônia: a fronteira agrícola 20 anos depois; organizado por Philippe Lena e Adélia Engracia de Oliveira. - Belém: Museu Paraense Emilio Goeldi, 1991.

ANUÁRIO DO PARÁ 2014 - 2015/ Jornal Diário do Pará. - v. 2, n. 2, 2014. - Belém: O Jornal Liberal, 2014.

ARAÚJO, Isaac Fonseca. Território de ação local: uma etnografia da vida associativa na Amazônia tocantina. Belém, UFPA: 2015.

BEKER, Bertha K. Amazônia: geopolítica na virada do III milênio. Rio de Janeiro: Garamond, 2006.

DA SILVA. Bruno; AMORIM. Tanielle Santos. A produção, venda e renda do açaí: um estudo no município de Igarapé-Miri /PA. 2017.

HARVEY, David [2001]. A produção capitalista do espaço. Tradução: Carlos Szlak. São Paulo: Annablume, 2005 .

IBGE. Censo 2000/2010. Disponível em: <http://www.cidades.ibge.gov.br//>. Acesso em: 30 Nov. 2016.

LIMA, Ana Lúcia Sales; PEREIRA, Luciene Maria Pires. História do Brasil Colônia. Maringá - PR: UniCesumar, 2015.

LOBATO, Eládio. Caminho de Canoa Pequena. $3^{\text {a }}$ ed Belém: Nazaré, 2007.

LOBATO, Cesarina Corrêa; SOARES, Crisálinda Pantoja. Prismas Sobre Educação em Cultura em IgarapéMiri no Século XX. Belém: Imprensa Oficial do Estado do Pará, 2001. 
OLIVEIRA, Agostinho Monteiro Gonçalves d'. Chronica de Igarape'-Miry. Belém: Imprensa Oficial, 1899.

PARÁ, Carlos. Revista PPZ 2165. DRT/PA. 2018.

PEREIRA. E. A. As encruzilhadas das territorialidades ribeirinhas: Transformações no exercício espacial do poder em comunidades ribeirinhas da Amazônia Tocantina Paraense. Tese de doutorado. Niterói. 2014.

PIMENTEL. G.T. Formação socioespacial do município de Igarapé-Miri-Pa e sua periodização. Trabalho de conclusão de curso. Belém-Pa. 2017.

REVISTA ELETRÔNICA GLOBO RURAL. Disponível em:

https://revistagloborural.globo.com/Noticias/Sustentabilidade/noticia/2018/09/exposicao-propoe-

alternativas-para-seguranca-de-coletores-de-acai.html>. Acesso em: 22 set. 2018.

SANTIAGO, J. Igarapé-Miri: A verdadeira terra da cachaça. Belém: FCPTN, 2013.

SANTOS, Milton. (2008). A natureza do espaço. Técnica e Tempo. Razão e Emoção. São Paulo: Editora da Universidade de São Paulo.

SANTOS, Milton. Espaço e Sociedade. $2^{\text {a }}$ Ed. Petrópolis: Vozes, 1979.

SANTOS, Milton; SILVEIRA, Maria Laura. O Brasil: território e sociedade no início do século XXI. $11^{\text {a }}$ ed. Rio de Janeiro: Record, 2008.

SEMED, Secretaria Municipal de Educação de Igarapé-Miri, 2017. Disponível em:<http://semedmiri17.blogspot.com.br/>. Acesso em 02 Fev. 2017.

TAVARES, Maria Goretti da Costa. Geopolítica Portuguesa, Controle e Formação Territorial na Amazônia dos séculos XVII-XVIII: os fortes, as missões e a política pombalina. VI Congresso da Geografia Portuguesa Lisboa, 17-20 de Outubro de 2007. 